\title{
Measurement of PD-L1 in melanoma: a quantitative antibody comparison
}

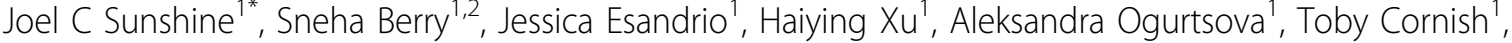 \\ Evan J Lipson ${ }^{1,2}$, Robert A Anders ${ }^{1}$, Janis M Taube ${ }^{1}$ \\ From 30th Annual Meeting and Associated Programs of the Society for Immunotherapy of Cancer (SITC 2015) \\ National Harbor, MD, USA. 4-8 November 2015
}

\section{Background}

Immunohistochemical detection of PD-L1 may be used in the future as a biomarker to help select an immunotherapeutic regimen for patients with advanced melanoma. For example, patients whose tumors are PD-L1+ may receive anti-PD-1 monotherapy, and those whose tumors are PD-L1(-) may receive combination anti-PD-1 and anti-CTLA-4. The evaluation of the utility of PD-L1 as a biomarker has been hampered by the different antibodies and assays used. The purpose of this study was to quantitatively compare staining properties of three different PD-L1 monoclonal antibodies that have been used in recent landmark publications.

\section{Methods}

Immunohistochemistry for PD-L1 was performed on serial sections from fourteen formalin-fixed paraffin-embedded archival melanoma samples using three different monoclonal antibodies: 5h1, SP142, and E1L3N. Slides were imaged using the Vectra Automated Quantitative Pathology Imaging System, and using intensity thresholds set by two pathologists, were scored for the percentage of total cells (melanocytes and immune cells) demonstrating PD-L1 staining. The observed staining intensity in the samples below the threshold considered to be "positive" by the pathologists was used as a measure of background staining for each antibody.

\section{Results}

Membranous PD-L1 expression in melanoma samples detected with $5 \mathrm{~h} 1$ and SP142 was highly correlated (Figure 1A, R2 $=0.88, \mathrm{p}<0.0001$ ). However, there was no significant correlation between the results obtained with E1L3N vs $5 \mathrm{~h} 1$ (Figure $1 \mathrm{~B}, \mathrm{R}^{2}=0.11, \mathrm{p}=0.25$ ) or

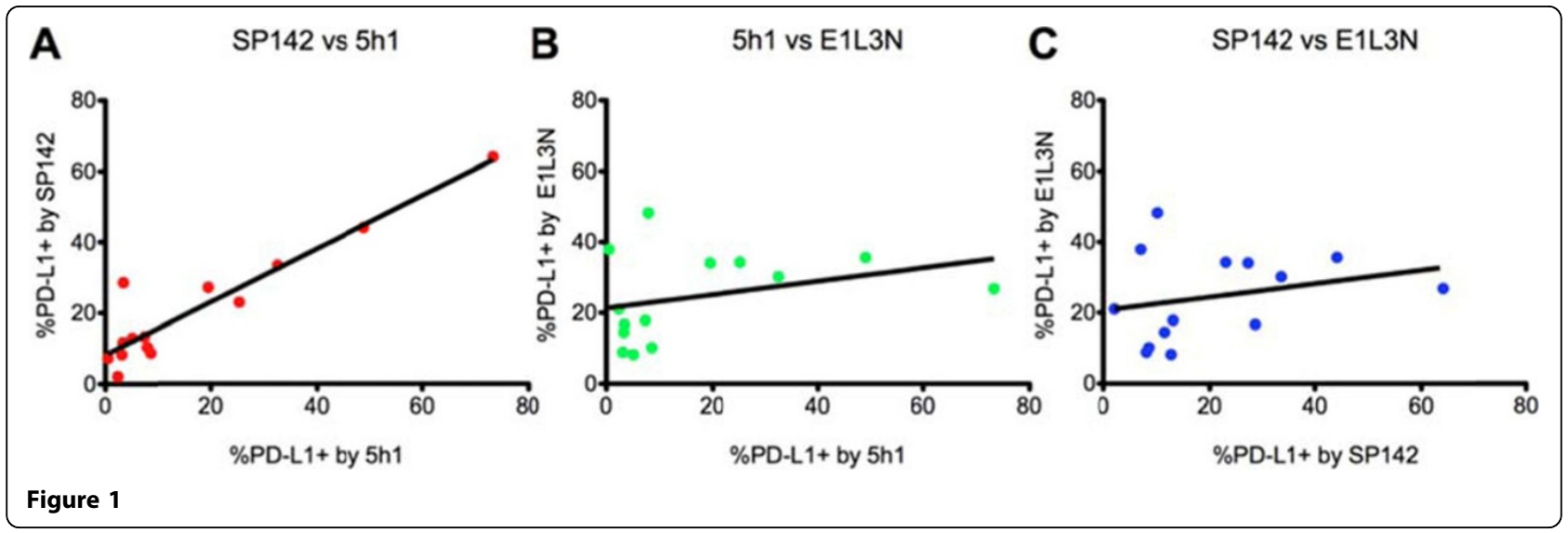

'Johns Hopkins University School of Medicine, Baltimore, MD, USA

Full list of author information is available at the end of the article

(C) 2015 Sunshine et al. This is an Open Access article distributed under the terms of the Creative Commons Attribution License (http:// 
SP142 (Figure $1 C, \mathrm{R} 2=0.07, \mathrm{p}=0.36$ ). The best fit line predicts that a specimen stained with $5 \mathrm{~h} 1$, which scored as having 5\% membranous PD-L1 expression, would show $12 \%$ PD-L1+ cells (95\% confidence interval of $7.5 \%$ to $16.1 \%$ ) when stained with SP142. 5 h1 showed the lowest background staining, with the lowest intensity of staining in cells that were considered by the pathologists to represent PD-L1-negative cells. SP142 demonstrated staining properties very close to $5 \mathrm{~h} 1$, but with slightly higher background staining intensity. E1L3N showed a higher background staining intensity than either of the other two clones, resulting in a less evident discrimination between PD-L1+ vs. PD-L1(-) cells.

\section{Conclusions}

The commercially available clone SP142 demonstrates comparable staining properties to $5 \mathrm{~h} 1$, while the E1L3N, at least under the conditions used in this study, does not. Similar comparisons including additional proprietary clones, such as $28-8$ and $22 \mathrm{C} 3$, will be essential in understanding how best to use reported PD-L1 status from various assays to guide therapeutic selection in patients with advanced melanoma.

\section{Authors' details}

${ }^{1}$ Johns Hopkins University School of Medicine, Baltimore, MD, USA. ${ }^{2}$ Sidney Kimmel Comprehensive Cancer Center, Baltimore, MD, USA.

Published: 4 November 2015

doi:10.1186/2051-1426-3-S2-P107

Cite this article as: Sunshine et al:: Measurement of PD-L1 in melanoma: a quantitative antibody comparison. Journal for ImmunoTherapy of Cancer 2015 3(Suppl 2):P107.
Submit your next manuscript to BioMed Central and take full advantage of:

- Convenient online submission

- Thorough peer review

- No space constraints or color figure charges

- Immediate publication on acceptance

- Inclusion in PubMed, CAS, Scopus and Google Scholar

- Research which is freely available for redistribution

Submit your manuscript at www.biomedcentral.com/submit 